Desi Nurmaida: Analisis Pengaruh Tingkat Inflasi

\title{
ANALISIS PENGARUH TINGKAT INFLASI, TRANSAKSI PASAR UANG ANTAR BANK SYARIAH (PUAS) DAN INVESTASI SYARIAH TERHADAP IMBAL HASIL SERTIFIKAT BANK INDONESIA SYARIAH (SBIS)
}

\author{
Desi Nurmaida \\ Karyawan Bank Tabungan Pensiunan Nasioanal Syariah Kota Medan \\ e_mail : desi.nurmaida.aritonang@gmail.com
}

\begin{abstract}
Abstrak
Penelitian ini bertujuan untuk menganalisis pengaruh tingkat inflasi, transaksi Pasar Uang Antar Bank Syariah (PUAS) dan investasi syariah terhadap imbal hasil Sertifikat Bank Indonesia Syariah (SBIS). Data yang digunakan adalah data time series periode Januari 2012 - Desember 2017 yang dipublikasikan oleh Bank Indonesia dan Otoritas Jasa Keuangan (OJK). Metode analisis yang digunakan dalam penelitian ini adalah model Vector Auto Regression (VAR). Hasil analisis Kausalitas Granger (Granger Causality) menunjukkan bahwa, ada pola hubungan kausalitas satu arah antara inflasi dengan transaksi Pasar Uang Antar Bank Syariah (PUAS) dan imbal hasil Sertifikat Bank Indonesia Syariah (SBIS), ada pola hubungan kausalitas satu arah antara investasi syariah dengan transaksi Pasar Uang Antar Bank Syariah (PUAS) dan tidak ada pola hubungan kausalitas antara imbal hasil Sertifikat Bank Indonesia Syariah (SBIS) dengan transaksi Pasar Uang Antar Bank Syariah (PUAS) dan investasi syariah di Indonesia periode 2012-2017. Hasil analisis Impulse Response Function (IRF) menunjukkan bahwa, respon inflasi paling cepat mencapai kestabilan saat terjadi guncangan/shock pada variabel transaksi Pasar Uang Antar Bank Syariah (PUAS). Respon transaksi Pasar Uang Antar Bank Syariah (PUAS) paling cepat mencapai kestabilan saat terjadi guncangan/shock pada variabel investasi syariah. Respon investasi syariah paling cepat mencapai kestabilan saat terjadi guncangan/shock pada variabel investasi syariah. Respon imbal hasil Sertifikat Bank Indonesia Syariah (SBIS) paling cepat mencapai kestabilan saat terjadi guncangan/shock pada variabel transaksi Pasar Uang Antar Bank Syariah (PUAS). Hasil analisis Variance Decomposition (VD) menunjukkan bahwa, variabel yang memberikan kontribusi paling besar terhadap inflasi, transaksi Pasar Uang Antar Bank Syariah (PUAS), investasi syariah dan imbal hasil Sertifikat Bank Indonesia Syariah (SBIS) adalah inflasi, transaksi Pasar Uang Antar Bank Syariah (PUAS), investasi syariah dan imbal hasil Sertifikat Bank Indonesia Syariah (SBIS) itu sendiri.
\end{abstract}

Kata Kunci: Tingkat Inflasi, PUAS, Investasi Syariah, SBIS

\begin{abstract}
This research aims to analyze the effect level of inflation, transaction of interbank sharia money market and sharia investment to yield sharia certificate of Bank Indonesia period January 2012 - December 2017. The data used are time series data period
\end{abstract}


j-EBIS Vol. 3 No. 2 Juni 2018

January 2012 - December 2017 published by BI and OJK. The method of analysis used in this research is Vector Auto Regression (VAR) models. Results of Granger Causality analysis show that, there is a pattern of one-way causality between inflation with transaction of interbank sharia money market (PUAS) and yield sharia certificate of Bank Indonesia (SBIS), there is a pattern of one-way causality between sharia investment with transaction of interbank sharia money market (PUAS) and there is not a pattern of one-way causality between yield sharia certificate of Bank Indonesia (SBIS) with transaction of interbank sharia money market (PUAS) and sharia investment in Indonesia period 2012-2017. Results of Impulse Response Function analysis show that, inflation response most quickly reach stability when shock occur in the variable transaction of interbank sharia money market (PUAS). Transaction of interbank sharia money market (PUAS) response most quickly reach stability when shock occur in the variable sharia investment. Sharia investment response most quickly reach stability when shock occur in the variable sharia investment. Yield sharia certificate of Bank Indonesia (SBIS) response most quickly reach stability when shock occur in the variable transaction of interbank sharia money market (PUAS). Result of Variance Decomposition analysis show that, the variable that gives the most contribution to inflation, transaction of interbank sharia money market (PUAS), sharia investment and yield sharia certificate of Bank Indonesia (SBIS) is inflation, transaction of interbank sharia money market (PUAS), sharia investment and yield sharia certificate of Bank Indonesia (SBIS) it self.

Keywords: Inflation, Transaction of Interbank Sharia Money Market And Sharia Investment To Yield Sharia Certificate of Bank Indonesia

\section{PENDAHULUAN}

Inflasi merupakan acuan utama pembentukan suku bunga. Bila tren inflasi naik, maka tren suku bunga selalu bergerak beriringan. Inflasi adalah tren kenaikan harga barang. Kenaikan harga barang akan menggeser daya beli masyarakat dan akan berpengaruh kepada peningkatan biaya simpanan dana (deposito).

Senada dengan teori di atas, dapat diketahui pula bahwa acuan suku bunga di Indonesia adalah Sertifikat Bank Indonesia (SBI) untuk yang konvensional dan Sertifikat Bank Indonesia Syariah (SBIS) untuk yang syariah. Besaran bunga Sertifikat Bank Indonesia (SBI) maupun tingkat imbal hasil Sertifikat Bank Indonesia Syariah (SBIS) juga dipengaruhi oleh besarnya tekanan laju inflasi. Karena inflasi menjadi indikator utama pembentukan suku bunga maupun imbal hasil terhadap produk yang diterbitkan oleh Bank Indonesia.

Sertifikat Bank Indonesia Syariah (SBIS) merupakan instrumen kebijakan moneter yang 
Desi Nurmaida: Analisis Pengaruh Tingkat Inflasi

ditetapkan Bank Indonesia sebagai pengganti dari Sertifikat Wadi'ah Bank Indonesia (SWBI). Sertifikat Wadiah Bank Indonesia (SWBI) merupakan instrumen kebijakan moneter yang pertama kali ditetapkan Bank Indonesia dalam sistem perbankan syariah di Indonesia sebagai instrumen penyerap likuiditas layaknya bank konvensional.

Peraturan Bank Indonesia No. 26/7/PBI/2004 tentang Sertifikat Wadiah Bank Indonesia (SWBI) menyatakan bahwa, Sertifikat Wadiah Bank Indonesia (SWBI) adalah sertifikat yang diterbitkan Bank Indonesia sebagai bukti penitipan dana berjangka pendek dengan prinsip wadiah yang merupakan piranti dalam pelaksanaan pengendalian moneter semacam Sertifikat Bank Indonesia (SBI) dalam praktek perbankan konvensional.

Namun, setelah dikeluarkannya peraturan Bank Indonesia tentang Sertifikat Wadiah Bank Indonesia (SWBI), terdapat banyak keluhan dari pihak Bank Umum Syariah (BUS) maupun Unit Usaha Syariah (UUS) tentang dirasakannya nilai return pada penempatan dana Sertifikat Wadiah Bank Indonesia (SWBI) yang lebih rendah dibanding dengan penempatan dana bank konvensional di Sertifikat Bank Indonesia (SBI). Hal ini dapat dilihat dalam pasal 9 Peraturan Bank Indonesia No. 6/7PBI/2004 tentang Sertifikat Wadiah Bank Indonesia (SWBI) yang menjelaskan mengenai penitipan bonus atas penitipan dana wadi'ah yang dimaksud merupakan kewenangan Bank Indonesia.

Dapat dikatakan bahwa dalam pemberian bonus dari penempatan dana bank syariah maupun Unit Usaha Syariah yang ada pada Sertifikat Wadiah Bank Indonesia (SWBI) tergantung akan kebijakan serta anggaran dana yang dimiliki oleh Bank Indonesia sebagai tempat penitipan dana wadi'ahnya Bank Umum Syariah (BUS) maupun Unit Usaha Syariah (UUS). Sedangkan Bank Umum Syariah (BUS) maupun Unit Usaha Syariah (UUS) tidak mempunyai kekuatan kepada Bank Indonesia untuk meminta pada bonus yang dijanjikan oleh Bank Indonesia.

Dari keluhan Bank Umum Syariah (BUS) maupun Unit Usaha Syariah (UUS) tersebut, akhirnya Bank Indonesia mengeluarkan peraturan kembali yang mengatur ulang tentang instrumen penyerap likuiditas berdasarkan syariah untuk menguntungkan return terhadap dana yang ditempatkan Bank Umum Syariah (BUS) maupun Unit Usaha Syariah (UUS) dalam instrumen penyerap likuiditas moneter dan juga sebagai instrumen moneter yang tepat untuk diberikan kepada Bank Umum Syariah (BUS) maupun Unit Usaha Syariah (UUS) di Indonesia. 
j-EBIS Vol. 3 No. 2 Juni 2018

Selanjutnya pada tanggal 31 Maret 2008 diberlakukanlah Sertifikat Bank Indonesia Syariah setelah Bank Indonesia menerbitkan Peraturan Bank Indonesia No. 10/11/PBI/2008 tentang Sertifikat Bank Indonesia Syariah. Peraturan tersebut dikeluarkan setelah Bank Indonesia mendapat izin dari Dewan Syariah Nasional Majelis Ulama Indonesia berdasarkan fatwa DSN MUI No. 63/DSN-MUI/XII/2007 tentang Sertifikat Bank Indonesia Syariah dan fatwa DSN-MUI No. 64/DSN-MUI/XII/2007 tentang Sertifikat Bank Indonesia Syariah Ju'alah.

Adapun yang dimaksud dengan Sertifikat Bank Indonesia Syariah (SBIS) adalah surat berharga berdasarkan prinsip Islam berjangka waktu pendek dalam mata uang rupiah yang diterbitkan oleh Bank Indonesia. Tujuan dikeluarkannya Peraturan Bank Indonesia tentang Sertifikat Bank Indonesia Syariah ini adalah sebagai salah satu instrumen operasi pasar terbuka dalam rangka pengendalian moneter yang dilakukan berdasarkan prinsip syariah.

Selain Sertifikat Bank Indonesia Syariah (SBIS), perbankan syariah di Indonesia juga menggunakan Pasar Uang Antar Bank Syariah (PUAS) sebagai alat untuk meminimalisasi likuiditas berlebih. Pasar Uang Antar Bank Syariah (PUAS) merupakan instrumen utama yang digunakan sebelum Sertifikat Bank Indonesia Syariah (SBIS), karena proses pelelangan di Pasar Uang Antar Bank Syariah (PUAS) jauh lebih mudah dan dapat dilakukan setiap hari. Sehingga likuiditas yang dilakukan lewat Pasar Uang Antar Bank Syariah (PUAS) lebih banyak tentunya. Hal ini dapat dibuktikan dari tingginya volume transaksi Pasar Uang Antar Bank Syariah (PUAS) pada bulan April tahun 2015 yang mencapai Rp. 587 miliar dibanding transaksi Sertifikat Bank Indonesia Syariah (SBIS) pada bulan yang sama yakni Rp 328 miliar.

Namun, tren pembentukan imbal hasil Pasar Uang Antar Bank Syariah (PUAS) yang dilakukan lebih dipengaruhi oleh kemampuan perbankan itu sendiri dalam mengelola likuiditasnya. Sehingga terkadang imbal hasil di Pasar Uang Antar Bank Syariah (PUAS) lebih rendah bila mengacu ke imbal hasil di Sertifikat Bank Indonesia Syariah (SBIS). Terlihat dari tingkat imbal hasil Sertifikat Bank Indonesia Syariah (SBIS) pada Juli tahun 2016 sebesar 6,85\% seperti yang terlihat pada Tabel. 1. Persen imbal hasil Sertifikat Bank Indonesia Syariah (SBIS) tersebut lebih tinggi daripada imbal hasil Pasar Uang Antar Bank Syariah (PUAS) pada periode yang sama yakni 2,94\%. Hal tersebut berbanding terbalik dengan investasi syariah yang mengalami peningkatan pada tahun 2015 pada bulan yang 
Desi Nurmaida: Analisis Pengaruh Tingkat Inflasi

sama sebesar 2,83\%. Peningkatan investasi syariah, ketika imbal hasil Pasar Uang Antar Bank Syariah (PUAS) mengalami penurunan, sedangkan investasi syariah mengalami kenaikan. Hal tersebut akan disajikan oleh peneliti pada tabel di bawah ini.

Tabel. 1.

Pergerakan Inflasi, Transaksi Pasar Uang Antar Bank Syariah (PUAS), Investasi Syariah Dan Imbal Hasil Sertifikat Bank Indonesia Syariah

(SBIS) Tahun 2015

\begin{tabular}{|c|c|c|c|c|}
\hline Bulan & Inflasi (\%) & $\begin{array}{c}\text { PUAS } \\
\text { (Trilyun Rupiah) }\end{array}$ & $\begin{array}{c}\text { rSBIS } \\
(\%)\end{array}$ & $\begin{array}{c}\text { Investasi } \\
\text { (Trilyun Rupiah) }\end{array}$ \\
\hline Januari & 6.96 & 0.592 & 6.993 & 0.041 \\
\hline Februari & 6.29 & 0.375 & 6.672 & 0.041 \\
\hline Maret & 6.38 & 0.225 & 6.652 & 0.044 \\
\hline April & 6.79 & 0.347 & 6.660 & 0.044 \\
\hline Mei & 7.15 & 0.130 & 6.661 & 0.045 \\
\hline Juni & 7.26 & 0.258 & 6.699 & 0.046 \\
\hline Juli & 7.26 & 0.255 & 6.685 & 0.046 \\
\hline Agustus & 7.18 & 0.323 & 6.800 & 0.046 \\
\hline September & 6.83 & 0.260 & 7.150 & 0.048 \\
\hline Oktober & 6.25 & 0.060 & 7.150 & 0.047 \\
\hline November & 4.89 & 0.020 & 7.150 & 0.048 \\
\hline Desember & 3.35 & 0.160 & 7.150 & 0.052 \\
\hline
\end{tabular}

Sumber: Laporan Statistik Bank Indonesia (data dikelola)

Dari tabel di atas dapat dilihat bahwa imbalan Sertifikat Bank Indonesia Syariah (SBIS) pada tahun 2015 tidak begitu berfluktuasi. Imbal hasil Sertifikat Bank Indonesia Syariah (SBIS) tertinggi untuk tahun 2015 terjadi pada bulan Juli ke bulan September yakni sebesar 6,85\% naik menjadi 7,64\%. Seiring dengan kenaikan imbalan Sertifikat Bank Indonesia Syariah (SBIS) tersebut, inflasi juga mengalami penurunan dari 7,26\% pada bulan Juli menjadi $6,85 \%$ pada bulan September.

Sedangkan transaksi Pasar Uang Antar Bank Syariah (PUAS) mengalami penurunan untuk waktu yang sama yakni dari 2,98 \% di bulan juli, hingga 2,39 pada bulan September. Hal ini menunjukkan bahwa, meskipun transaksi Pasar Uang Antar Bank Syariah (PUAS) lebih mudah karena bisa dilakukan setiap hari, namun karena kebijakan Bank Indonesia untuk menyerap kelebihan likuiditas berlebih.

Untuk itu Bank Indonesia akan berupaya untuk menawarkan imbal hasil Sertifikat Bank Indonesia Syariah (SBIS) berada di atas imbalan Pasar Uang Antar Bank Syariah (PUAS). Dengan demikian terdapat kemungkinan Bank Syariah akan memilih untuk mengalokasikan dananya di Sertifikat Bank Indonesia Syariah (SBIS). Selain itu, Sertifikat Bank Indonesia Syariah (SBIS) lebih dijamin karena dikelola oleh Bank Indonesia sebagai bank 
j-EBIS Vol. 3 No. 2 Juni 2018

sentral.

Berangkat dari uraian latar belakang masalah di atas, perlu dilakukan penelitian untuk menguji apakah inflasi dan transaksi Pasar Uang Antar Bank Syariah (PUAS) akan mempengaruhi tingkat imbal hasil Sertifikat Bank Indonesia Syariah (SBIS). Untuk itu penulis tertarik untuk mengambil judul “Pengaruh Inflasi, Transaksi Pasar Uang Antar Bank Syariah, dan Investasi Syariah terhadap Imbal Hasil Sertifikat Bank Indonesia Syariah (SBIS)”.

\section{Batasan Masalah}

Berdasarkan dari latar belakang di atas, di sini peneliti akan membatasi masalah yang akan diteliti, yang terdiri dari tiga variabel bebas (dependent variable) dan satu variabel terikat (independent variable). Adapun variabel bebas yang akan dibahas oleh peneliti adalah inflasi, Pasar Uang Antar Bank Syariah (PUAS) dan investasi syariah Sedangkan pada varibel terikat adalah imbal hasil Sertifikat Bank Indonesia Syariah (SBIS). Data yang akan diambil adalah data bulanan dari tahun 2012 sampai dengan tahun 2017.

\section{Perumusan Masalah}

Masalah penelitian harus dirumuskan dengan tegas dan jelas, sehingga mudah diketahui ruang lingkup masalah dan arah kegiatan yang akan dilakukan. Rumusan masalah dapat diajukan dalam bentuk pertanyaan yang menuntut jawaban dalam penelitian yang akan dilakukan.

Adapun rumusan masalah pada penelitian ini yang sudah disusun secara sistematis yaitu: “Bagaimana pengaruh inflasi, Pasar Uang Antar Bank Syariah (PUAS) dan investasi syariah secara parsial maupun secara simultan terhadap imbal hasil Sertifikat Bank Indonesia Syariah (SBIS) periode 2012-2017?”

\section{Kajian Teori}

\section{Teori Inflasi Konvensional}

Pada mulanya inflasi diartikan sebagai kenaikan jumlah uang beredar atau kenaikan likuiditas dalam sebuah perekonomian. Pengertian tersebut mengacu pada gejala umum yang ditimbulkan oleh adanya kenaikan jumlah uang beredar di masyarakat yang diduga telah menyebabkan terjadinya kenaikan harga-harga. Dalam perkembangan lebih lanjut, inflasi secara singkat Inflasi dapat didefenisikan sebagai kecenderungan menaiknya harga-harga barang dan jasa secara umum berlangsung terus-menerus. 
Desi Nurmaida: Analisis Pengaruh Tingkat Inflasi

Dalam pengertian tersebut terdapat dua motif penting yang merupakan kunci dalam memahami pengertian dari inflasi. Motif yang pertama adalah kenaikan harga secara umum dan motif yang kedua adalah terus menerus. Kenaikan harga secara umum dikatakan sebagai motif penting dalam inflasi karena hanya kenaikan harga yang terjadi secara umum yang dapat disebut sebagai inflasi. Hal ini perlu diketahui untuk membedakan kenaikan atas barang dan jasa tertentu. Misalnya, kenaikan harga gula dan harga beras saja belum cukup dikatakan sebagai inflasi. Inflasi adalah kenaikan harga-harga secara umum dalam artian bahwa inflasi harus menggambarkan kenaikan harga sejumlah besar barang dan jasa yang dikonsumsi dalam suatu perekonomian.

Motif kedua adalah terus menerus dimana kenaikan harga yang terjadi karena faktor musiman, misalnya hanya terjadi menjelang hari-hari besar atau kenaikan harga sekali saja dan tidak mempunyai pengaruh lanjutan juga tidak cukup untuk disebut inflasi karena kenaikan harga dalam kasus tersebut bukan masalah kronis ekonomi.

Menurut Paul A. Samuelson, seperti sebuah penyakit, inflasi dapat digolongkan menurut tingkat keparahannya, yaitu sebagai berikut:

1) Moderate Inflation. Karakteristik inflasi pada tingkat ini adalah kenaikan tingkat harga yang lambat. Umumnya disebut sebagai inflasi satu digit. Pada tingkat inflasi seperti ini orang-orang masih mau memegang uang dan lebih cenderung menyimpan kekayaannya dalam bentuk uang daripada dalam bentuk aset riil.

1) Galloping Inflation. Inflasi jenis ini terjadi pada kisaran $20 \%$ hingga $200 \%$ pertahun. Pada tingkatan ini, orang-orang hanya memegang uang seperlunya saja, sedangkan kekayaan disimpan dalam bentuk aset riil. Orang akan menumpuk barang-barang dan memilih investasi dalam bentuk properti dan tanah. Pasar uang akan mengalami penyusutan dan pengalokasian dana dan pemberian pinjaman disalurkan dengan tingkat bunga yang sangat tinggi. Banyak perekonomian yang mengalami tingkat inflasi seperti ini mampu bertahan dan selamat walaupun sistem harganya berlaku sangat buruk.

2) Hiper Inflation. Yaitu proses kenaikan harga-harga yang sangat cepat yang menyebabkan tingkat harga menjadi dua atau beberapa kali lipat dalam waktu yang singkat. Inflasi ini terjadi pada tingkatan yang sangat tinggi dengan kisaran jutaan triliunan persen per tahun. Tidak pernah ada pemerintahan yang mampu selamat dari inflasi jenis ini. Sebagai contoh adalah Wiemar Republic di Jerman pada tahun 1920-an 
j-EBIS Vol. 3 No. 2 Juni 2018

Selain itu, inflasi dapat digolongkan sesuai dari penyebab-penyebabnya yaitu sebagai berikut:

1) Inflasi tarikan permintaan (demand pull inflation) adalah inflasi terjadi apabila sektor perusahaan tidak mampu dengan cepat melayani permintaan yang wujud dalam pasaran. Masalah kekurangan barang akan berlaku dan mendorong kepada kenaikan harga-harga.

\section{Gambar. 1.}

\section{Kurva Demand-Pull Inflation}

Harga

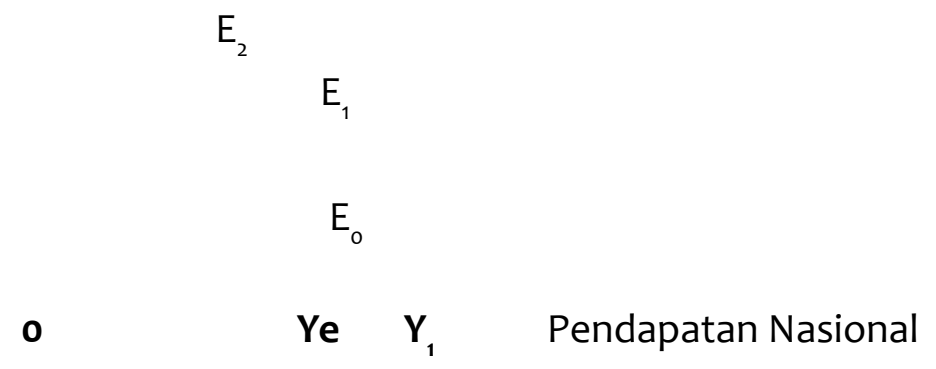

Berdasarkan gambar di atas, diasumsikan bahwa permintan agregat bertambah, sehingga kurva AD bergeser ke kanan menjadi AD. Akibatnya tingkat harga dan output naik di sepanjang kurva SRAS, masing-masing dari $\mathrm{P}_{0}$ menjadi $\mathrm{P}_{1}$ dan dari Ye menjadi $Y_{1}$.

Dalam jangka panjang, pendapatan nasional akan kembali menuju tingkat keseimbangan yang menunjukkan full employment (Ye). Akibatnya, tingkat harga naik menjadi $\mathrm{P}_{1}$ dan keseimbangan baru tercapai pada titik $\mathrm{E}_{2}$.

1) Inflasi desakan biaya (cost push inflation) merupakan masalah kenaikan hargaharga dalam perekonomian yang disebabkan oleh kenaikan biaya produksi. Pertambahan biaya produksi akan mendorong perusahaan-perusahaan menaikkan harga walaupun mereka harus mengambil resiko akan menghadapi pengurangan dalam permintaan barang-barang yang diproduksinya. 


\section{Gambar. 2.}

\section{Kurva Cost-Push Inflation}

$\begin{array}{ccc}\text { Harga } & \mathrm{AS}_{2} & \mathrm{AS}^{1} \\ \mathbf{P}_{2} & \mathrm{E}_{2} & \mathrm{E}^{2} \\ \mathbf{P}_{1} & & \end{array}$

0

$Y_{1} \quad$ Ye Pendapatan Nasional

Berdasarkan gambar di atas, diasumsikan bahwa keseimbangan ekonomi mula-mula terjadi pada titik $E_{1}$ dengan permintaan agregat ( $A D$ ) dan penawaran agregat (AS). Misalkan karyawan menuntut kenaikan gaji. Akibatnya kurva AS bergeser ke kiri dari $A S^{1}$ menjadi $A S^{2}$. Tingkat harga naik dari $\mathrm{P}_{1}$ menjadi $\mathrm{P}_{2}$ dan output turun dari Ye menjadi $Y_{1}$ dengan keseimbangan baru tercapai pada titik $\mathrm{E}_{2}$.

3) Inflasi juga dapat disebabkan oleh kebijakan pemerintah untuk menambah jumlah uang beredar dalam masyarakat (monetary inflation), misalnya dengan cara pencetakan uang baru, pengeluaran kembali uang lama sehingga jumlah uang beredar semakin banyak.

Inflasi memiliki dampak positif dan dampak negatif, tergantung parah atau tidaknya inflasi. Apabila inflasi itu ringan, justru mempunyai pengaruh yang positif dalam arti dapat mendorong perekonomian lebih baik, yaitu meningkatkan pendapatan dan membuat orang bergairah untuk bekerja, menabung dan mengadakan investasi. Sebaliknya, dalam masa inflasi yang parah, yaitu pada saat terjadi inflasi tak terkendali (hiper inflasi), keadaan perekonomian menjadi kacau dan perekonomian dirasakan lesu (seperti keadaan pada tahun 1997 inflasi mencapai 70\%). Orang menjadi tidak bersemangat kerja, menabung, atau mengadakan investasi dan produksi karena harga meningkat dengan cepat.

Menurut Prathama Rahardja dan Manurung, dampak inflasi terhadap individu dan masyarakat di antaranya:

1) Menurunnya tingkat kesejahteraan masyarakat 
j-EBIS Vol. 3 No. 2 Juni 2018

Inflasi menyebabkan daya beli masyarakat menjadi berkurang atau malah semakin rendah, apalagi bagi orang-orang yang berpendapatan tetap, kenaikan upah tidak secepat kenaikan harga-harga, maka inflasi ini akan menurunkan upah riil setiap individu yang berpendapatan tetap.

2) Memperburuk distribusi pendapatan

Bagi masyarakat yang berpendapatan tetap akan menghadapi kemerosotan nilai riil dari pendapatannya dan pemiliki kekayaan dalam bentuk uang akan mengalami penurunan juga.

Sedangkan dampak inflasi bagi perekonomian secara keseluruhan, misalnya prospek pembangunan ekonomi jangka panjang akan semakin memburuk, inflasi mengganggu stabilitas ekonomi dengan merusak rencana jangka panjang para pelaku ekonomi. Dampak inflasi bagi perekonomian nasional, antara lain:

1) Investasi berkurang

2) Mendorong tingkat bunga

3) Mendorong penanam modal yang bersifat spekulatif

4) Menimbulkan kegagalan pelaksanaan pembangunan

5) Menimbulkan ketidakpastian keadaan ekonomi di masa depan

6) Menyebabkan daya saing produk nasional berkurang

7) Menimbulkan defisit neraca pembayaran

8) Meningkatnya jumlah pengangguran

\section{Teori Inflasi Dalam Islam}

Pada mulanya, Islam tidak mengenal inflasi, karena mata uangnya stabil dengan digunakannya mata uang dinar dan dirham. Penurunan nilai dinar dan dirham masih mungkin terjadi, yaitu ketika nilai emas yang menopang nilai nominal dinar itu mengalami penurunan, di antaranya akibat ditemukannya emas dalam jumlah yang besar, tetapi keadaan seperti ini sangat kecil kemungkinannya. Kondisi defisit pernah terjadi pada masa Rasulullah SAW dan ini hanya terjadi satu kali yaitu sebelum perang Hunain.

Al-Maqrizi menyatakan bahwa peristiwa inflasi merupakan sebuah fenomena alam yang menimpa kehidupan masyarakat sejak masa dahulu hingga sekarang. Inflasi menurutnya terjadi ketika harga-harga secara umum mengalami kenaikan dan berlangsung terus menerus. Pada saat seperti ini, persediaan barang dan jasa mengalami kelangkaan, sehingga para konsumen yang dikarenakan sangat membutuhkan barang tersebut harus 
Desi Nurmaida: Analisis Pengaruh Tingkat Inflasi

mengeluarkan lebih banyak uang untuk sejumlah barang dan jasa yang sama, sehingga perputaran uang di masyarakat terus meningkat.

Al-Maqrizi dalam bukunya Iqhalah juga mengidentifikasikan bahwa administrasi politik menjadi sangat lemah dan buruk disebabkan pegawai pemerintah bisa menduduki jabatannya karena memberikan suap. Akibatnya ketika menjabat, orang yang menyuap tadi kemudian menerapkan pajak yang menindas untuk menutup ongkos yang telah dikeluarkan untuk menyuap. Dorongan untuk bekerja dan berproduksi menjadi bertolak belakang dan hasil produksi menurun. Krisis diperburuk dengan penurunan mata uang, karena pengeluaran mata uang tembaga (fulus) yang berlebihan untuk menutupi defisit anggaran negara. Faktor-faktor tersebut ditambah dengan paceklik mendorong kepada tingginya tingkat inflasi, penderitaan rakyat kecil, dan kemiskinan negara.

Menurut para ahli ekonomi Islam, inflasi berakibat sangat buruk bagi perekonomian karena:

1) Menimbulkan gangguan terhadap fungsi uang, terutama terhadap fungsi tabungan (nilai simpan), fungsi dari unit perhitungan.

2) Melemahkan semangat menabung dan sikap terhadap menabung dari masyarakat (turunnya Marginal Propensity to Consume).

3) Meningkatkan kecenderungan untuk berbelanja terutama untuk non-primer dan barang-barang mewah (naiknya Marginall Propensity to Consume).

4) Mengarahkan investasi pada hal-hal yang non-produktif yaitu penumpukan kekayaan (hoarding) seperti: tanah, bangunan, logam mulia, mata uang asing dengan mengorbankan investasi ke arah produktif seperti pertanian, industrial perdagangan, transportasi, dan lainnya.

Ekonom Islam, Taqiuddin Ahmad ibn Al-Maqrizi mengklasifikasikan inflasi berdasarkan faktor penyebabnya ke dalam dua hal, yaitu:

1) Inflasi yang disebabkan oleh faktor alamiah (Natural Inflation) Inflasi jenis pertama inilah yang terjadi pada masa Rasulullah SAW dan Khulafaurrasyidin, yaitu karena kekeringan atau karena peperangan. Sesuai dengan namanya, inflasi jenis ini diakibatkan oleh sebab-sebab alamiah, di mana orang tidak mempunyai kemampuan untuk mencegahnya. Al-Maqrizi mengatakan bahwa inflasi ini adalah inflasi yang diakibatkan oleh turunnya Penawaraan Agregatif (AS) atau naiknya permintaan Agregatif (AD). 
j-EBIS Vol. 3 No. 2 Juni 2018

1) Inflasi yang disebabkan oleh kesalahan manusia (Human Error Inflation). Inflasi akibat kesalahan manusia ini disebabkan oleh tiga hal, yaitu korupsi dan administrasi yang buruk (corruption and bad administration), pajak yang memberatkan (expensive tax), serta jumlah uang yang berlebihan (excessive seigno). Kenaikan harga-harga yang terjadi adalah dalam bentuk jumlah uangnya, bila dalam bentuk dinar jarang sekali terjadi kenaikan. Al-Maqrizi mengatakan supaya jumlah uang dibatasi hanya pada tingkat minimal yang dibutuhkan untuk transaksi pecahan yang kecil saja.

Sertifikat Bank Indonesia Syariah yang selanjutnya disebut SBIS adalah surat berharga berdasarkan prinsip syariah berjangka waktu pendek dalam mata uang rupiah yang diterbitkan oleh Bank Indonesia. Hal ini sedikit berbeda dengan Sertifikat Bank Indonesia (SBI) konvensional yang diterbitkan melalui lelang dengan tingkat diskonto yang berbasis bunga (interest) sedangkan Sertifikat Bank Indonesia Syariah (SBIS) diterbitkan menggunakan akad/kontrak transaksi jualah.

Adapun pengertian akad jualah dalam penjelasan peraturan Bank Indonesia No. 10/11/ PBI/2008 Tentang Sertifikat Bank Indonesia Syariah (SBIS) sama dengan Fatwa Dewan Syariah Nasional Majelis Ulama Indonesia No. 64/DSN-MUI/XII/2007 Tentang Akad Ju'alah yaitu suatu janji atau komitmen (iltizam) untuk memberikan imbalan tertentu ('iwadah/ ju'l) atas pencapaian hasil (natijah) yang ditentukan dari suatu pekerjaan.

Dalam Fatwa Dewan Sayariah Nasional Majelis Ulama Indonesia No.64/DSN-MUI/XII/2007 Tentang Sertifikat Bank Indonesia (SBI) menerangkan sistem tentang penggunaan akad jualah pada Sertifikat Bank Indonesia Syariah (SBIS), Bank Indonesia bertindak sebagai ja'il (pemberi pekerjaan) dan bank syariah sebagai ma'jullah (penerima pekerjaan) dan objek (ma'jul alaihnya) adalah partisipasi dari bank syariah yang turut serta membantu kebijakan moneter Bank Indonesia melalui penyerapan likuiditas dari masyarakat dan menempatkannya di Bank Indonesia dalam waktu dan jumlah tertentu.

Sertifikat Bank Indonesia Syariah (SBIS) sudah mempunyai legalitas yuridis secara hukum Islam sesuai dengan pertimbangan Dewan Fatwa Majelis Ulama Indonesia (MUI) yang merujuk pada Al-Qur'an dan Hadits sebagai dasar hukum imbal hasil Sertifikat Bank Indonesia Syariah (SBIS). Salah satu diantaranya dalam QS. Yusuf: 72 yaitu: 
Desi Nurmaida: Analisis Pengaruh Tingkat Inflasi

Penyeru-penyeru itu berkata: "Kami kehilangan piala Raja, dan siapa yang dapat mengembalikannya akan memperoleh bahan makanan (seberat) beban unta, dan aku menjamin terhadapnya".

Kalimat ".......dan siapa yang dapat mengembalikannya akan memperoleh bahan makanan (seberat) beban unta,......" dalam QS. Yusuf ayat 72 di atas merupakan penekanan terhadap akad ju'alah. Hal ini dapat dilihat bahwa, kalimat ini merupakan kalimat janji untuk memberikan imbalan/upah terhadap suatu pekerjaan. Dalam penelitian ini dikaitkan dengan imbal hasil yang diberikan Bank Indonesia atas keikutsertaan bank syariah dalam melaksanakan kebijakan moneternya dengan menyerap likuiditas berlebih dari masyarakat.

\section{Metodologi Penelitian}

\section{Analisis Data}

Metode analisis data yang digunakan dalam penelitian ini analisa kuantitatif dengan menggunakan model Vector Auto Regression (VAR). Vector Auto Regression (VAR) adalah pengembangan model ADL. Metodologi VAR pertama kali dikemukakan oleh Sims (1980). Dimana Vector Auto Regression (VAR) memungkinkan asumsi variabel yang bersifat eksogen untuk melakukan estimasi terhadap serangkaian variabel yang diduga mengalami endogenitas.

Secara umum terdapat tiga bentuk model Vector Auto Regression (VAR) yaitu:

1) Unrestricted Vector Auto Regression (VAR), model ini terkait dengan persoalan kointegrasi dan hubungan teoritis. Jika data yang digunakan dalam permodelan Vector Auto Regression (VAR) data yang stasioner pada level, maka bentuknya adalah Unrestricted Vector Auto Regression (VAR). Ada dua bentuk dari unrestricted Vector Auto Regression (VAR), yaitu Vector Auto Regression (VAR) in level dan Vector Auto Regression (VAR) in difference. Vector Auto Regression (VAR) in level digunakan jika data sudah stasioner pada tingkat level sedangkan Vector Auto Regression (VAR) in difference digunakan jika data tidak stasioner pada level dan tidak memiliki hubungan kointegrasi, maka estimasi Vector Auto Regression (VAR) dilakukan dalam bentuk data difference.

1) Restricted Vector Auto Regression (VAR) atau disebut Vector Error Correction Model (VECM), yaitu bentuk Vector Auto Regression (VAR) yang terestriksi, hal ini terjadi apabila data tidak stasioner namun terkointegrasi. 
j-EBIS Vol. 3 No. 2 Juni 2018

2) Struktural Vector Auto Regression (VAR) merupakan bentuk Vector Auto Regression (VAR) yang direstriksi berdasarkan hubungan teoritis yang kuat dan skema ordering (urutan) peta hubungan terhadap peubah-peubah yang digunakan dalam model Vector Auto Regression (VAR). Oleh karena itu, Struktural Vector Auto Regression (VAR) dikenal dengan bentuk VAR yang teoritis.

Berikut model persamaan yang dapat diolah yakni satu model untuk masing-masing variabel yang akan diteliti :

$$
\begin{aligned}
& r S B I S_{t}=\alpha+\beta_{1} r S B I S_{t-p}+\beta_{2} I N F_{t-p}+\beta_{3} \text { PUAS }_{t-p}+\beta_{4} I V S_{t-p}+\varepsilon_{t} \\
& I N F_{\mathrm{I}}=\alpha+\beta_{1} I N F_{t-p}+\beta_{2} \text { PUAS }_{t-p}+\beta_{3} I V S_{t-p}+\beta_{4} r S B I S_{t-p}+\varepsilon_{t} \\
& \text { PUAS }_{t}=\alpha+\beta_{1} \text { PUAS }_{t-p}+\beta_{2} \text { IVS }{ }_{t-p}+\beta_{3} \text { rSBIS }_{t-p}+\beta_{4} I N F_{t-p}+\varepsilon_{t} \\
& I V S_{t}=\alpha+\beta_{1} I V S_{t-p}+\beta_{2} r S B I S_{t-p}+\beta_{3} I N F_{t-p}+\beta_{4} P U A S_{r-p}+\varepsilon_{t}
\end{aligned}
$$

Keterangan:

INF = Inflasi

PUAS = Transaksi Pasar Uang Antar Bank Syariah (PUAS)

IVS = Investasi Syariah

rSBIS = Imbal Hasil Seritifikat Bank Indonesia Syariah (SBIS)

Analisis bertahap yang dilakukan dalam Vector Auto Regression (VAR)/ Vector Error Correction Model (VECM) adalah uji stasioneritas, penentuan lag optimal, analisis model Vector Auto Regression (VAR), uji kausalitas granger, uji IRF, dan uji variance decomposition.

1. Uji Stasioneritas

Pada analisis runtun waktu, asumsi bahwa data adalah stasioner merupakan sifat yang penting. Pada model stasioner, sifat-sifat statistik di masa yang akan datang akan dapat diramalkan berdasarkan data historis yang telah terjadi di masa yang lalu. Data time series umumnya bersifat stokastik (memiliki tren yang tidak stasioner/data tersebut memiliki akar unit. Jika data memiliki akar unit maka cenderung berfluktuasi tidak di sekitar nilai rata-ratanya sehingga menyulitkan dalam estimasi model. Uji kestasioneran data dapat dilakukan melalui pengujian terhadap ada tidaknya unit root dalam varibel dengan Augmented Dickey Fuller (ADF), dengan adanya unit root akan menghasilkan persamaan atau model regresi lancung. Adapun persamaan uji stasioner dengan analisis Augmented Dickey Fuller (ADF) sebagai berikut : 


$$
\Lambda Y_{t}=\alpha_{D}+\gamma Y_{t-1}+\beta_{1} \sum_{i=1}^{p} \Lambda Y_{t-i+1}+\varepsilon_{t}
$$

Dimana :

$\mathrm{Y}_{\mathrm{r}}$ : Bentuk dari first difference

$\mathrm{c}_{0}:$ Intersep

$\mathrm{Y} \quad$ : Variabel yang diuji stasioneritasnya

$\mathrm{P} \quad$ : Panjang lag yang digunakan dalam model

$\varepsilon$ : Error term

Hipotesis nol ditolak jika nilai statistik Augmented Dickey Fuller (ADF) memiliki nilai kurang (lebih negatif) dibandingkan dengan nilai daerah kritik, maka jika hipotesis nol ditolak data bersifat stasioner.

Dengan kata lain dalam persamaan tersebut Ho menunjukkan adanya unit root (akar unit) dan $\mathrm{H}_{1}$ menunjukkan tidak adanya unit root (akar unit). Jika dalam uji stasioneritas ini menunjukkan nilai Augmented Dickey Fuller (ADF) statistik lebih kecil (lebih negatif) dari Mackinnon Critical Value, maka dapat diketahui bahwa data tersebut stasioner karena tidak mengandung akar unit. Sebaliknya, jika nilai Augmented Dickey Fuller (ADF) statistik lebih besar (tidak lebih negatif) dari Mackinnon Critical Value maka dapat disimpulkan bahwa data tersebut tidak stasioner.

1. Penentuan lag optimal

Estimasi Vector Auto Regression (VAR) sangat peka terhadap panjang lag yang digunakan. Terdapat dua cara untuk menentukan orde lag. Yang pertama menggunakan uji restriksi koefisien yang merupakan generalisasi dari uji restriksi pada persamaan regresi tunggal. Penentuan jumlah lag (ordo) yang akan digunakan dalam model VAR yang kedua dapat ditentukan berdasarkan kriteria berikut:

Akaike Information Criterion (AIC) $:^{-2\left(\frac{1}{T}\right)+2(k+T)}$

Schwarz Information Criterion (SIC) : $-2\left(\frac{1}{T}\right)+k \frac{\log (T)}{T}$

Hannan Quinnon (HQ)

$$
:^{-2\left(\frac{1}{T}\right)+2 k \log \left(\frac{\log (T)}{T}\right)}
$$

Dimana :

1 = Nilai fungsi log likelihood yang sama jumlahnya dengan 
j-EBIS Vol. 3 No. 2 Juni 2018

$$
\begin{aligned}
& -\frac{T}{2}\left(1+\log (2 \pi)+\log \left(\frac{s^{*} \sigma^{t}}{\tau}\right)\right) ; \Sigma^{\prime \prime} \varepsilon^{\prime} \text { merupakan sum of squared residual } \\
\mathrm{T} & =\text { Jumlah observasi } \\
\mathrm{k} & =\text { Parameter yang diestimasi }
\end{aligned}
$$

Lag optimal dapat dilihat dari nilai statistik kriteria informasi yang dihitung bagi setiap lag. Lag optimal adalah lag dengan nilai statistik kriteria informasi yang terkecil (AIC, SC, FPE dan HQ) atau kriteria LR yang terbesar. Penggunaan juga kriteria berganda dapat dilakukan untuk pencarian lag yang lebih optimal.

2. Uji Stabilitas Model Vector Auto Regression (VAR)

Untuk menguji kestabilan sistem Vector Auto Regression (VAR) yang telah ditentukan setelah penentuan lag maka perlu dilakukan pengujian dengan roots of Characteristic Polynomial. Jika dari hasil pengujian menunjukkan roots memiliki modulus yang lebih kecil dari 1, maka model tersebut dapat dikatakan stabil. Dan jika sistem Vector Auto Regression (VAR) stabil pada bagian output bawahnya akan muncul dua kalimat berikut: No root lies outside the unit circle. Vector Auto Regression (VAR) satisfies the stability condition. Dan jika Vector Auto Regression (VAR) tidak stabil akan muncul peringatan sebagai berikut: Warning : At least one root outside the unit circle. Vector Auto Regression (VAR) does not satisfy the stability condition.

3. Uji Kausalitas Granger

Metode yang digunakan untuk menganalisis hubungan kausalitas antar variabel yang diamati dengan uji kausalitas granger. Tujuannya untuk arah dan hubungan di antara variabel-variabel. Secara umum persamaan granger dapat diinterpretasikan sebagai berikut:

a. Unindirectional Causality dari variabel dependen ke variabel independen. Hal ini terjadi ketika koefisien lag variabel dependen secara statistik siginifikan berbeda dengan nol, sedangkan koefisien lag seluruh variabel independen sama dengan nol.

a. Feedback/billateral causality jika koefisien seluruh lag variabel baik variabel dependen maupun independen secara statistik signifikan berbeda dengan nol.

b. Independence jika koefisien lag seluruh variabel baik variabel dependen maupun independen secara statistik tidak berbeda dengan nol.

Granger causality adalah murni suatu konsep statistik. Dalam konsep ini suatu variabel $X$ dikatakan menyebabkan $Y$ jika realisasi $X$ terjadi terlebih dahulu daripada $Y$ dan realisasi $Y$ tidak mendahului realisasi $X$. Dengan demikian uji kausalitas granger dapat diuji dengan model Vector Auto Regression (VAR). 
1. Analisis Impulse Response Function (IRF)

Model Vector Auto Regression (VAR) juga dapat digunakan untuk melihat dampak perubahan dari satu peubah dalam sistem terhadap peubah lainnya dalam sistem secara dinamis. Caranya dengan memberikan guncangan (shock) pada salah satu peubah endogen. Penelusuran pengaruh guncangan sebesar satu standar deviasi yang dialami oleh satu peubah di dalam sistem terhadap nilai-nilai semua peubah saat ini dan beberapa periode mendatang yang disebut dengan teknik Impulse Response Function.

Fungsi Impulse Response Function (IRF) menggambarkan ekspektasi k-periode ke depan dari kesalahan prediksi suatu variabel akibat inovasi dari variabel yang lain. Lamanya pengaruh dari shock suatu variabel terhadap variabel lain sampai pengaruhnya hilang atau kembali ke titik keseimbangan dapat dilihat dengan analisis Impulse Response Function (IRF).

4. Uji Variance Decomposition

Variance Decomposition atau disebut juga forecast error variance decomposition merupakan perangkat dari model Vector Auto Regression (VAR) yang akan memisahkan variasi dari sejumlah variabel yang diestimasi menjadi komponen-komponen shock atau menjadi variabel innovation dengan asumsi bahwa variabel-variabel innovation tidak saling berkorelasi. Kemudian variance decomposition akan memberikan informasi mengenai proporsi dari pergerakan pengaruh shock pada sebuah variabel terhadap shock variabel lainnya pada periode saat ini dan periode yang akan datang. Jika dalam Impulse Response Function (IRF) digunakan untuk melihat dampak guncangan dari satu peubah terhadap peubah lainnya, sedangkan analisis ini bertujuan untuk menggambarkan relatif pentingnya setiap peubah dalam sistem Vector Auto Regression (VAR) karena adanya shock.

\section{PEMBAHASAN}

Analisis Variance Decomposition bertujuan untuk menggambarkan relatif pentingnya setiap peubah dalam sistem Vector Auto Regression (VAR) karena adanya shock. Variance decomposition bertujuan untuk mengukur besarnya kontribusi atau komposisi pengaruh masing-masing variabel independen terhadap variabel dependennya.

Berikut ini disajikan hasil analisis Variance Decomposition dengan menggunakan bantuan Program Eviews. 8.0.: 
j-EBIS Vol. 3 No. 2 Juni 2018

Tabel. 22.

Hasil Analisis Variance Decomposition

\begin{tabular}{|c|c|c|c|c|c|}
\hline $\begin{array}{l}\text { Variance Decomposi- } \\
\text { tion of INFLASI: } \\
\text { Period }\end{array}$ & S.E. & INFLASI & PUAS & INVESTASI & SBIS \\
\hline 1 & 0.671524 & 100.0000 & 0.000000 & 0.000000 & 0.000000 \\
\hline 2 & 0.908986 & 98.98146 & 0.831978 & 0.161555 & 0.025010 \\
\hline 3 & 1.071450 & 97.34372 & 2.167459 & 0.445220 & 0.043598 \\
\hline 4 & 1.193583 & 95.52996 & 3.628697 & 0.793194 & 0.048148 \\
\hline 5 & 1.288529 & 93.74563 & 5.034241 & 1.175847 & 0.044283 \\
\hline 6 & 1.363211 & 92.07126 & 6.310701 & 1.578443 & 0.039594 \\
\hline 7 & 1.422093 & 90.52904 & 7.437687 & 1.993239 & 0.040035 \\
\hline 8 & 1.468431 & 89.11716 & 8.418154 & 2.415350 & 0.049338 \\
\hline 9 & 1.504762 & 87.82609 & 9.263792 & 2.840762 & 0.069360 \\
\hline 10 & 1.533132 & 86.64556 & 9.988371 & 3.265491 & 0.100583 \\
\hline $\begin{array}{l}\text { Variance Decomposi- } \\
\quad \text { tion of PUAS: } \\
\text { Period }\end{array}$ & S.E. & INFLASI & PUAS & INVESTASI & SBIS \\
\hline 1 & 0.608897 & 0.200816 & 99.79918 & 0.000000 & 0.000000 \\
\hline 2 & 0.697182 & 0.228750 & 99.29410 & 0.280985 & 0.196164 \\
\hline 3 & 0.721547 & 0.782399 & 97.90267 & 0.841722 & 0.473208 \\
\hline 4 & 0.731721 & 1.888192 & 95.86552 & 1.549006 & 0.697279 \\
\hline 5 & 0.740643 & 3.331702 & 93.57116 & 2.276694 & 0.820443 \\
\hline 6 & 0.750611 & 4.831463 & 91.35700 & 2.951955 & 0.859587 \\
\hline 7 & 0.761046 & 6.177425 & 89.41770 & 3.552290 & 0.852580 \\
\hline 8 & 0.771020 & 7.265054 & 87.82115 & 4.082366 & 0.831433 \\
\hline 9 & 0.779921 & 8.071090 & 86.55823 & 4.555330 & 0.815354 \\
\hline 10 & 0.787500 & 8.619298 & 85.58402 & 4.983669 & 0.813017 \\
\hline $\begin{array}{l}\text { Variance Decomposi- } \\
\text { tion of INVESTASI: } \\
\text { Period }\end{array}$ & S.E. & INFLASI & PUAS & INVESTASI & SBIS \\
\hline 1 & 0.002014 & 0.848177 & 25.49427 & 73.65756 & 0.000000 \\
\hline 2 & 0.002643 & 0.492921 & 14.79893 & 84.63278 & 0.075370 \\
\hline 3 & 0.003170 & 0.372518 & $13 \cdot 50125$ & 85.76585 & 0.360386 \\
\hline 4 & 0.003644 & 0.288141 & 15.64353 & 83.21150 & 0.856831 \\
\hline 5 & 0.004060 & 0.251228 & 18.15830 & 80.08654 & 1.503923 \\
\hline 6 & 0.004418 & 0.372083 & 20.08689 & 77.30425 & 2.236776 \\
\hline 7 & 0.004727 & 0.769734 & 21.27915 & 74.95114 & 2.999980 \\
\hline 8 & 0.004995 & 1.531741 & 21.82523 & 72.89436 & 3.748667 \\
\hline 9 & 0.005233 & 2.699475 & 21.86636 & 70.98577 & 4.448402 \\
\hline 10 & 0.005448 & 4.267293 & 21.53889 & 69.11866 & 5.075156 \\
\hline $\begin{array}{l}\text { Variance Decomposi- } \\
\text { tion of SBIS: } \\
\text { Period }\end{array}$ & S.E. & INFLASI & PUAS & INVESTASI & SBIS \\
\hline 1 & 0.250170 & 0.145133 & 0.447727 & 0.021915 & 99.38523 \\
\hline 2 & 0.332612 & 8.994090 & 0.705717 & 0.538785 & 89.76141 \\
\hline 3 & 0.400701 & 21.35283 & 1.520277 & 1.189751 & 75.93715 \\
\hline 4 & 0.463660 & 32.74323 & 2.222966 & 1.716661 & 63.31715 \\
\hline
\end{tabular}


Desi Nurmaida: Analisis Pengaruh Tingkat Inflasi

\begin{tabular}{|cccccc|}
\hline 5 & 0.521716 & 41.85073 & 2.701893 & 2.058644 & 53.38874 \\
6 & 0.574212 & 48.80178 & 3.015861 & 2.241887 & 45.94047 \\
7 & 0.620893 & 54.06146 & 3.234509 & 2.310420 & 40.39361 \\
8 & 0.661909 & 58.06403 & 3.405321 & 2.303165 & 36.22748 \\
9 & 0.697646 & 61.14010 & 3.555845 & 2.249648 & 33.05441 \\
10 & 0.728595 & 63.52689 & 3.700665 & 2.170995 & 30.60145 \\
\hline Cholesky Ordering: & & & & & \\
INFLASI PUAS INVESTA- & & & & & \\
SI SBIS & & & & & \\
\hline
\end{tabular}

Sumber: Hasil Analisis Eviews. 8.0

Berdasarkan Tabel. 22. dapat diketahui bahwa:

- Pada horizon prediksi 10 periode variabel Inflasi, sekitar 95\% varians dari prediksi bersumber dari variabel Inflasi dan PUAS.

- Pada horizon prediksi 10 periode variabel PUAS, sekitar 95\% varians dari prediksi bersumber dari variabel PUAS dan Inflasi.

- Pada horizon prediksi 10 periode variabel Investasi Syariah, sekitar 95\% varians dari prediksi bersumber dari variabel Investasi Syariah dan PUAS.

- Pada horizon prediksi 10 periode variabel SBIS, sekitar 95\% varians dari prediksi bersumber dari variabel SBIS dan Inflasi.

\section{KESIMPULAN}

Berdasarkan uraian dan hasil penelitian yang telah dikemukakan di atas maka dapat diambil kesimpulan bahwa, hasil uji akar unit (Unit Root Test) menunjukkan bahwa data runtun waktu (time series) variabel inflasi $\left(X_{1}\right)$, variabel transaksi Pasar Uang Antar Bank Syariah (PUAS) $\left(X_{2}\right)$, variabel investasi syariah $\left(X_{3}\right)$ dan variabel imbal hasil Sertifikat Bank Indonesia Syariah (SBIS) (Y) di Indonesia periode 2012 - 2017 tidak mengalami masalah akar unit atau seluruh data stasioner.

Hasil analisis penentuan lag optimal untuk estimasi Vector Auto Regression (VAR) berdasarkan nilai statistik metode Likelihood Ratio (LR), Akaike Information Criterion (AIC), Final Prediction Error (FPE), Schwartz Information Criterion (SC) dan Hannan-Quinn Information Criterion (HQ) adalah lag 1.

Hasil analisis stabilitas model Vector Auto Regression (VAR) dengan menggunakan Roots of Characteristic Polynomial menunjukkan bahwa, seluruh nilai roots memiliki modulus yang lebih kecil dari 1 (satu) sehingga dapat disimpulkan bahwa, model Vector Auto Regression (VAR) dalam penelitian ini dapat dikatakan stabil. 
j-EBIS Vol. 3 No. 2 Juni 2018

Hasil analisis Kausalitas Granger (Granger Causality) menunjukkan bahwa, ada pola hubungan kausalitas satu arah antara inflasi dengan transaksi Pasar Uang Antar Bank Syariah (PUAS) dan imbal hasil Sertifikat Bank Indonesia Syariah (SBIS) di Indonesia selama periode 2012 - 2017, dimana perubahan inflasi pada setiap tahunnya akan mempengaruhi perubahan transaksi Pasar Uang Antar Bank Syariah (PUAS) dan imbal hasil Sertifikat Bank Indonesia Syariah (SBIS) setiap tahunnya dan sebaliknya perubahan transaksi Pasar Uang Antar Bank Syariah (PUAS) dan imbal hasil Sertifikat Bank Indonesia Syariah (SBIS) setiap tahunnya tidak mempengaruhi perubahan inflasi setiap tahunnya.

Hasil analisis Kausalitas Granger (Granger Causality) menunjukkan bahwa, ada pola hubungan kausalitas satu arah antara investasi syariah dengan transaksi Pasar Uang Antar Bank Syariah (PUAS) di Indonesia selama periode 2012 - 2017, dimana perubahan transaksi Pasar Uang Antar Bank Syariah (PUAS) pada setiap tahunnya akan mempengaruhi perubahan investasi syariah setiap tahunnya dan sebaliknya perubahan investasi syariah setiap tahunnya tidak mempengaruhi perubahan transaksi Pasar Uang Antar Bank Syariah (PUAS) setiap tahunnya.

Hasil analisis Kausalitas Granger (Granger Causality) menunjukkan bahwa, tidak ada pola hubungan kausalitas antara imbal hasil Sertifikat Bank Indonesia Syariah (SBIS) dengan transaksi Pasar Uang Antar Bank Syariah (PUAS) dan investasi syariah di Indonesia selama periode 2012 - 2017, dan tidak ada pola hubungan kausalitas antara investasi syariah dengan inflasi di Indonesia selama periode 2012 - 2017.

Hasil analisis Impulse Response Function (IRF) menunjukkan bahwa, respon inflasi paling cepat mencapai kestabilan saat terjadi guncangan/shock pada variabel transaksi Pasar Uang Antar Bank Syariah (PUAS). Respon transaksi Pasar Uang Antar Bank Syariah (PUAS) paling cepat mencapai kestabilan saat terjadi guncangan/shock pada variabel investasi syariah. Respon investasi syariah paling cepat mencapai kestabilan saat terjadi guncangan/shock pada variabel investasi syariah. Respon imbal hasil Sertifikat Bank Indonesia Syariah (SBIS) paling cepat mencapai kestabilan saat terjadi guncangan/shock pada variabel transaksi Pasar Uang Antar Bank Syariah (PUAS).

Hasil analisis Variance Decomposition (VD) menunjukkan bahwa, variabel yang memberikan kontribusi paling besar terhadap inflasi, transaksi Pasar Uang Antar Bank Syariah (PUAS), investasi syariah dan imbal hasil Sertifikat Bank Indonesia Syariah (SBIS) adalah 
Desi Nurmaida: Analisis Pengaruh Tingkat Inflasi

inflasi, transaksi Pasar Uang Antar Bank Syariah (PUAS), investasi syariah dan imbal hasil Sertifikat Bank Indonesia Syariah (SBIS) itu sendiri.

\section{SARAN}

Berdasarkan hasil penelitian yang diperoleh, maka penulis mencoba untuk memberikan saran yang berkaitan dengan inflasi, transaksi Pasar Uang Antar Bank Syariah (PUAS), investasi syariah dan imbal hasil Sertifikat Bank Indonesia Syariah (SBIS) periode 2012 2017, antara lain:

1. Bagi Perbankan Syariah Indonesia, hendaknya tetap memperhatikan setiap pergerakan dari variabel makroekonomi khususnya tingkat inflasi dikarenakan pergerakan dari variabel makroekonomi khususnya tingkat inflasi tersebut berpengaruh terhadap perubahan transaksi Pasar Uang Antar Bank Syariah (PUAS) dan imbal hasil Sertifikat Bank Indonesia Syariah (SBIS) pada setiap tahunnya.

1. Bagi Pemerintah, hendaknya senantiasa mengendalikan laju inflasi sehingga dapat memicu pertumbuhan ekonomi dalam negeri. Pertumbuhan ekonomi yang baik tentunya akan mendorong perkembangan dunia usaha dan perbankan syariah.

2. Bagi Masyarakat, hendaknya tidak terlalu terpengaruh terhadap setiap pergerakan dari variabel makroekonomi khususnya inflasi karena perbankan syariah yang berdasarkan sistem bagi hasil dipastikan mampu bertahan terhadap situasi krisis keuangan yang buruk. Jadi, kepercayaan masyarakat untuk menggunakan jasa perbankan syariah dalam setiap aktivitas usahanya secara tidak langsung akan berpengaruh terhadap penempatan sebagian aset perbankan syariah pada Bank Indonesia dalam bentuk Sertifikat Bank Indonesia Syariah (SBIS).

3. Bagi Akademisi, sebaiknya dapat melakukan penelitian kembali terkait imbal hasil Sertifikat Bank Indonesia Syariah (SBIS) dengan memasukkan variabel-variabel seperti Reksadana Syariah, Obligasi Syariah dan lain sebagainya.

\section{DAFTAR PUSTAKA}

Aduardus, Tandelilin, Analisis Investasi dan Manajemen Portofolio, Yogyakarta: BPFE, 2001.

Ariefianto, Moch Doddy, Ekonometrika: Esensi dan Aplikasi Menggunakan Eviews, Jakarta: Erlangga, 2012.

As Suyuti, Al Asbah wan Nadzo ir, Beirut: Dar al-Fikr,1996.

Chapra, Umer, The Future Of Economics, An Islamic Perspective, Jakarta: SEBI, 2001. 
j-EBIS Vol. 3 No. 2 Juni 2018

Departemen Agama RI, Al-Qur`an dan Terjemahnya, Yogyakarta: Dana Bhakti Wakaf, 1995.

Efferin, Sujuko, Metode Penelitian Akuntansi, Yogyakarta: Graha Ilmu, 2008.

Halim, Abdul, Analisis Investasi, Jakarta: Salemba Empat, 2003.

Hasanah, Dini, Analisis Jalur Pembiayaan Dalam Mekanisme Transmisi Kebijakan Moneter di Indonesia dengan Metode VAR/VECM, dlm. Buku Panduan Forum Riset Perbankan Syariah III 2010 IAIN SUMUT, Bahan-Bahan Terpilih dan Hasil Riset Terbaik, Bank Indonesia: Medan, 2010.

Huda, Nurul dan Heykal, Mohammad, Lembaga Keuangan Islam, Jakarta: Kencana, 2010.

Juanda, Bambang dan Junaidi, Ekonometrika Deret Waktu, Bogor: IPB Press, 2012.

Karim, Adiwarman, Ekonomi Makro Islami, Jakarta: Raja Grafindo Persada, 2008.

, Sejarah Pemikiran Ekonomi Islam, Jakarta: Raja Grafindo Persada, 2008.

Mankiw, Greegory N., Teori Makro Ekonomi, Jakarta: Erlangga, 2003.

Muhammad, Metodologi Penelitian Ekonomi Islam Pendekatan Kuantitatif, Jakarta: RajaGrafindo Persada, 2008.

Muhammad, Manajemen Bank Syari'ah, Yogyakarta: YKPN, 2002.

Rahardja, Prathama dan Manurung, Mandala, Teori Ekonomi Makro Suatu Pengantar Edisi Kedua, Jakarta: Lembaga Penerbit FE.UI, 2004.

Rais, Muhammad, Mushaf Jalalain, Al-Qur'an Terjemah Per Kata dan Tafsir Jalalain Per Kalimat, Tangerang: Pustaka Kibar, 2012.

Rivai, Veithzal, Bank and Financial Institutin Management, Jakarta: RajaGrafindo Persada, 2007.

Rosadi, Dedi, Analisis Ekonometrika dan Runtun Waktu Terapan dengan R, Yogyakarta: Andi, 2011.

Sabiq, Sayyid Fiqih Sunnah, Pustaka Imam Syafii: Bogor, 2009.

Sharfe, Wiliam F, Mutual Fund Formance, The Journal Of Business, Januari 1995.

Sholihin, Ahmad Ifham, Buku Pintar Ekonomi Syariah, Jakarta: Gramedia Pustaka Utama, 
2010.

Soemitra, Andri, Bank dan Lembaga Keuangan Syariah, Jakarta: Kencana, 2009.Sutedi, Adrian Perbankan Syariah, Tinjauan dan Beberapa Segi Hukum, Jakarta: Ghalia Indonesia, 2009.

Sugiono, Instrumen Pengendalian Moneter: Operasi Pasar Terbuka, Jakarta: Pusat Studi Kebanksentralan (PPSK), 2004.

Sugiyono, Metode Penelitian Administrasi, Bandung: Alfabeta, 2006.

Sukirno, Sadono, Teori Pengantar Makroekonomi, Jakarta: Raja Grafindo Persada, 2006.

Suseno dan Aisyah, Siti, Inflasi, Jakarta: Pusat Pendidikan Kebanksentralan (PPSK), 2009.

Sutedi, Adrian, Perbankan Syariah, Tinjauan dan Beberapa Segi Hukum, Jakarta: Ghalia Indonesia, 2009.

Wirasasmita, Rivai, Kamus Lengkap Ekonomi, Bandung : Pionir Jaya, 1999.

Wirdyaningsih, Bank dan Asuransi Islam di Indonesia, Jakarta: Kencana, 2006. 